\title{
Web of Science
}

1 Clarivate

Analytics
Search Search Results

Full Text from Publisher
Find PDF

\section{Effect of Annealing on Surface Oxidation of Ti-50.8 at\% Ni Shape Memory Alloy}

By: Sholihin, MHM (Sholihin, Mohamad Hanis Mohamad) ${ }^{[1]}$; Zaki, HHM (Zaki, Hafizah Hanim Mohd) ${ }^{[1]}$; Sarifuddin, N

(Sarifuddin, Norshahida) ${ }^{[1]}$; Hairin, ALN (Hairin, Assayidatul Laila Nor) ${ }^{[1]}$

MATERIALS CHARACTERIZATION USING X-RAYS AND RELATED TECHNIQUES

Edited by: Sulaiman, MA; Ahmad, ZA; Mohamed, JJ

Book Series: AIP Conference Proceedings

Volume: 2068

Article Number: UNSP 020003

Dol: $10.1063 / 1.5089302$

Published: 2019

Document Type: Proceedings Paper

\section{Conference}

Conference: International Conference on X-Rays and Related Techniques in Research and Industry (ICXRI)

Location: Kota Bharu, MALAYSIA

Date: AUG 18-19, 2018

Sponsor(s): Univ Malaysia Kelantan; X Rays Applicat Soc Malaysia

\section{Abstract}

Nowadays, the used of NiTi shape memory alloys in biomedical field is growing exponentially linear with technological advancement. With all great benefits from NiTi, however, they also come with certain level of toxicity that can harm human's health sourcing from the $\mathrm{Ni}$ itself. Many techniques have been developed to contain this Ni from leaching out from the NiTi shape memory alloys. Among the techniques, thermal oxidation via annealing treatment is chosen where TiO2 is expected to form on the surface of the NiTi shape memory alloys and may act as a barrier to prevent the Ni from leaching out. Therefore, this research investigates the effect of annealing treatment to produce the optimum thickness of the oxide layer with good martensitic transformation behavior. In this case, NiTi was annealed from 400 degrees $\mathrm{C}$ to 700 degrees $\mathrm{C}$ for duration of 10 to 300 minutes in a furnace. The thickness of oxide layer was characterized using SEM and the transformation behavior was analyzed using DSC equipment. Based on the results obtained from SEM and DSC, by increasing annealing temperature and time, the thickness of the oxide layer increases and more even, however, it reduces the enthalpy change. Therefore, samples annealed at 600 degrees $C$ for 50 to 150 minutes is an optimum parameter to produce the appropriate thickness and uniformity of the oxide layer (similar to $22-26 \mathrm{mu} \mathrm{m}$ ) with reasonable Ms and enthalpy changes (Delta $\mathrm{H}-\mathrm{A}$-> $M=7.50$ to 9.62 ).

\section{Author Information}

Reprint Address: Zaki, HHM (reprint author)

+ Int Islamic Univ Malaysia, Kulliyyah Engn, Dept Mfg \& Mat Engn, Jalan Gombak, Selangor, Malaysia.

Addresses:

+ [1] Int Islamic Univ Malaysia, Kulliyyah Engn, Dept Mfg \& Mat Engn, Jalan Gombak, Selangor, Malaysia

E-mail Addresses: hanissholihin@gmail.com; hafizahhanim@iium.edu.my;norshahida@iium.edu.my; assayidatul_laila@iium.edu.my

Funding

\begin{tabular}{|l|l|}
\hline Funding Agency & Grant Number \\
\hline International Islamic University Malaysia (IIUM) & RIGS16-080-0244 \\
\hline
\end{tabular}

View funding text

Publisher

AMER INST PHYSICS, 2 HUNTINGTON QUADRANGLE, STE 1NO1, MELVILLE, NY 11747-4501 USA

\section{Citation Network}

In Web of Science Core Collection

0

Times Cited

Create Citation Alert

7

Cited References

View Related Records

Use in Web of Science

Web of Science Usage Count

0

0

Last 180 Days $\quad$ Since 2013

Learn more

This record is from:

Web of Science Core Collection

- Conference Proceedings Citation Index-

Science

Suggest a correction

If you would like to improve the quality of the data in this record, please suggest a correction.

Categories / Classification

Research Areas: Materials Science; Physics 
Web of Science Categories: Materials Science, Multidisciplinary; Materials Science, Characterization \& Testing; Physics,

Applied

See more data fields

\section{Cited References: 7}

Showing 7 of $7 \quad$ View All in Cited References page

(from Web of Science Core Collection)

1. Nickel, its adverse health effects \& oxidative

Times Cited: 228

By: Das, K. K.; Das, S. N.; Dhundasi, S. A.

INDIAN JOURNAL OF MEDICAL RESEARCH Volume: 128 Issue: 4 Pages: 412-425 Published: OCT 2008

2. Surface Characterization of NiTi Superelastic and Shape Memory Alloys After Electrolytic Polishing

Times Cited: 4

By: de Azevedo Lopes, Natalia Isabel; de Oliveira Silva, Lais Avila; Santos, Leandro de Arruda; et al.

MATERIALS RESEARCH-IBERO-AMERICAN JOURNAL OF MATERIALS Volume: 20 Supplement: 2 Pages: $572-579$ Published: 2017

3. Assessing the biocompatibility of NiTi shape memory alloys used for medical applications

Times Cited: 163

By: Es-Souni, M; Es-Souni, M; Fischer-Brandies, $\mathrm{H}$

ANALYTICAL AND BIOANALYTICAL CHEMISTRY Volume: 381 Issue: 3 Pages: 557-567 Published: FEB 2005

4. Surface oxidation of NiTi shape memory alloy

Times Cited: 264

By: Firstov, GS; Vitchev, RG; Kumar, H; et al.

BIOMATERIALS Volume: 23 Issue: 24 Pages: 4863-4871 Article Number: PII S0142-9612(02)00244-2 Published: DEC 2002

5. Growth of oxide layers on NiTi alloy surfaces through anodization in nitric acid electrolyte

Times Cited: 3

By: Ohtsu, Naofumi; Hirano, Yuma

SURFACE \& COATINGS TECHNOLOGY Volume: 325 Pages: 75-80 Published: SEP 252017

6. Thermodynamic study of the low-temperature phase B19' and the martensitic transformation in near-equiatomic Ti-Ni shape memory alloys

By: Tang, WJ

METALLURGICAL AND MATERIALS TRANSACTIONS A-PHYSICAL METALLURGY AND MATERIALS SCIENCE Volume: 28 Issue: 3 Pages: $537-544$ Published: MAR 1997

7. Atomic Layer-Deposited TiO2 Coatings on NiTi Surface

Times Cited: 1

By: Vokoun, D.; Racek, J.; Kaderavek, L.; et al.

JOURNAL OF MATERIALS ENGINEERING AND PERFORMANCE Volume: 27 Issue: 2 Pages: 572-579 Published: FEB 2018

Showing 7 of $7 \quad$ View All in Cited References page

Clarivate

Accelerating innovation
() 2019 Clarivate Copyright notice Terms of use Privacystatement Cookie policy

Sign up for the Web of Science newsletter Follow us 